\author{
Krzysztof Pawlisz \\ Uniwersytet Papieski Jana Pawta II w Krakowie \\ Międzyuczelniany Instytut Muzyki Kościelnej, Kraków
}

\title{
Dzieło Jehana Titelouze'a i jego znaczenie w krystalizacji stylu organowego ${ }^{1}$
}

W bieżącym roku mija 450 lat od urodzin Jehana Titelouze'a. Rocznica ta może być pretekstem do przybliżenia sylwetki oraz twórczości tego francuskiego organisty i kompozytora. Mimo że Titelouze jednogłośnie nazywany jest przez francuską tradycję „ojcem francuskiej szkoły organowej”, pozostał niejako w cieniu kompozytorów następnych pokoleń. Nie można wszakże nie zauważyć, że należał on do innej epoki niż kompozytorzy tzw. „złotego wieku” (począwszy już od L. Couperina). Titelouze jest jeszcze głęboko zanurzony w XVI w.; jego formacja muzyczna, jego język muzyczny czy w ogóle jego mentalność jako kompozytora są zakorzenione i ściśle związane ze stylem polifonii renesansowej. W tym też kontekście należy widzieć jego twórczość. Jego dwie „księgi organowe” z roku 1623 i 1626 mają charakter zarówno epigoński, jak i prekursorski. Epigoński - ze względu na język muzyczny, wykorzystujący „stare” renesansowe techniki kontrapunktyczne (doprowadzone wszakże do niebywałej perfekcji). Charakter prekursorski dzieła Titelouze’a tkwi natomiast w nowatorskim podejściu do samego instrumentu: w nastawieniu na wyodrębnianie brzmieniowe poszczególnych linii melodycznych, co z kolei związane jest bezpośrednio z nowo powstającym typem organów francuskich. Jest to więc aspekt wykonawczo-brzmieniowy i na wskroś związany z francuskim dążeniem do subtelności. Twórczość Titelouze’a wpisuje się zatem w pewien ciąg, stanowiący o rozwoju i przemianach stylistycznych muzyki organowej we Francji. Choć pozornie nie ma ona bezpośredniego związku z muzyką organistów francuskich późniejszych generacji, stanowiła niewątpliwie jeden z niezbędnych etapów w ewolucji francuskiej muzyki organowej. Ponadto twórczość ta ukazuje w szczególnie wyrazisty sposób aspekt źródeł wokalnych muzyki organowej oraz drogi jej uniezależnienia się od stylu wokalnego.

1 Referat wygłoszony 6 maja 2013 w Akademii Muzycznej w Krakowie podczas ogólnopolskiej sesji naukowej Francuska muzyka organowa XVII i XVIII w. Jezyk muzyczny oraz problematyka wykonawcza dziet dawnych mistrzów. 
Jehan Titelouze urodził się najprawdopodobniej w roku $1563^{2}$ w mieście St-Omer ${ }^{3}$. Nie posiadamy dziś pewnych informacji na temat jego wykształcenia. Przypuszcza się jednak, że uczęszczał do przykatedralnej szkoły chóralnej w swoim rodzinnym mieście, gdzie prócz podstaw francuskiego i łaciny uczono także śpiewu, harmonii i kontrapunktút. Niewątpliwie też w takim środowisku zetknął się z tradycją i stylem muzyki wokalnej szkół niderlandzkich. Ten właśnie repertuar stanie się zasadniczym punktem odniesienia i źródłem inspiracji dla Titelouze’a jako kompozytora. W wieku około dwudziestu lat - prawdopodobnie już jako osoba duchowna - Titelouze przybył do normandzkiej stolicy Rouen, gdzie w roku 1585 otrzymał posadę organisty w kościele St-Jean, a trzy lata później, wykazując się szczególnymi zdolnościami improwizatorskimi, wygrał konkurs na stanowisko organisty roueńskiej katedry. Funkcję tę sprawował aż do śmierci, przez ponad 45 lat. W roku 1610 został mianowany kanonikiem katedralnym, otrzymując przy tym prebendę w Baillolet.

O jego twórczości z okresu pierwszych czterech dziesięcioleci aktywności zawodowej nie wiemy praktycznie nic. Dopiero w latach 20. XVII w. pojawiły się drukiem jego kompozycje: dwa zbiory utworów organowych oraz niezachowana msza wokalna Missa quatour vocum ad imitationem moduli „In Ecclesia”.

W latach 1622-1633 Titelouze korespondował ze słynnym filozofem, matematykiem i teoretykiem muzyki Marinem Mersenne’em. Zachowało się siedem listów Titelouze'a do Mersenne’a. Autor porusza w nich głównie kwestie związane z muzyką i teorią muzyki starogreckiej w kontekście ówczesnych prób wprowadzania ich w życie przez kompozytorów.

2 Chociaż rok ten nie jest w sposób jednoznaczny udokumentowany, podawany jest jednak przez większość biografów jako najbardziej prawdopodobny. Wiadomo, że w 1623 Titelouze został zdyspensowany z uczestniczenia w nocnych nabożeństwach. Dyspensę taką otrzymywało się w wieku 60 lat. A. Collette, A. Bourdon, Notice historique sur les orgues et les organistes de la cathédrale de Rouen, Rouen 1894, s. 19.

3 Saint-Omer aż do pokoju w Nimwegen w 1678 wchodziło w skład Niderlandów Hiszpańskich. Kompozytor został naturalizowany we Francji dopiero 9 sierpnia 1604 roku, po dziewięcioletnich staraniach, jako wieloletni już wówczas mieszkaniec Rouen.

4 M. Vanmackelberg, Titelouziana, „Recherches sur la musique française classique”, 1967, VII, s. 235.

5 Wiadomo ponadto, iż prócz tej mszy Titelouze skomponował jeszcze dwie inne, które również nie zachowały się do dziś. A. Pirro, Jean Titelouze, [w:] J. Titelouze-Oeuvres completes, Mainz 1903, s. XI. 
Titelouze nauczał ponadto gry organowej. Jego uczniami byli śpiewacy katedralnego chóru chłopięcego ${ }^{6}$.

Wśród tych licznych kierunków aktywności muzycznej Titelouze’a podkreślić trzeba jeszcze jeden, mianowicie działalność organologiczną. Począwszy od roku objęcia posady w katedrze, Titelouze regularnie zasiadał w komisjach nadzorujących przebieg remontów wielu instrumentów w Rouen, a także zapraszany był do współpracy w innych ośrodkach, m.in. w Poitiers czy Amiens. W roku 1600 sprowadził do Rouen (w celu rozbudowy organów katedralnych) wybitnego flamandzkiego organmistrza Crespina Carliera, który od tego czasu aktywny będzie w wielu północnych regionach Francji, a zwłaszcza w Paryżu. Od lat 20. natomiast Titelouze współpracował z Guillaume’em Lesselierem, Szkotem z pochodzenia i zarazem uczniem Carliera ${ }^{8}$. On to m.in. zrealizował projekt Titelouze'a organów w kościele St-Godard w Rouen.

Jehan Titelouze zmarł 25 października 1633 w Rouen w wieku 70 lat.

$*$

Jak zostało powyżej wspomniane, z twórczości Titelouze’a zachowały się do naszych czasów dwa zbiory utworów organowych: Hymnes de l'Eglise pour toucher sur l'orgue, avec les fugues et recherches sur leur plain-chant oraz Le Magnificat, ou cantique de la Vierge pour toucher sur l'orgue, suivant les huit tons de l'Eglise ${ }^{10}$. Oba wydane zostały w Paryżu, w oficynie Pierre'a Ballarda, odpowiednio w latach $1623^{11}$ i 1626 . Pierwszy zbiór zawiera opracowania dwunastu hymnów brewiarzowych. Ich wybór został podyktowany zarówno częstotliwo-

6 Znamy z nazwiska bodaj tylko pięciu z nich: Jean Van der Elst, Antoine Le Roy, Jacques Lefebvre, Vincent Jolliet, Florent Bienvenu.

7 Najważniejsze prace: Dunkerque (1590), St-Omer, Courtrai (1595), Gand (St-Michel, Notre-Dame, St-Jacques, 1596-1599), Namur (1598). Liczne instrumenty w Poitier oraz w katedrze (1611, przy odbiorze obecny m.in. Titelouze), Rouen (St-André, 1614), Gisors (przebudowa, 1618), Soissons (1621), Tours, Chartres, Paris (St-Jacques-de-la-Boucherie, St-Nicolas-des-Champs, 1632-1936, Grands-Augustains, 1633).

8 Urodzony w Aberdeen, nazywał się pierwotnie William Lesseli (Lessely) - w Rouen od 1611. Prace m.in.: Mortain (1617), St-Martin-de-Boscherville (1627), Rouen (St-Godard, 1632), Le Havre (Notre-Dame, 1636-1938).

9 Hymny kościelne do grania na organach jako fugi i ricercary [oparte] na ich [tychże hymnów] melodiach chorałowych.

${ }^{10}$ Magnificat lub kantyk [Marii] Panny do grania na organach, w ośmiu tonach kościelnych.

${ }^{11}$ Wydanie Hymnów zostało ponadto wznowione w roku 1624, co niewątpliwie świadczy o ich szerokim przyjęciu. 
ścią ich zastosowania, jak też rangą świąt, do których przynależą. Drugi zbiór zawiera natomiast osiem cykli Magnificat, z których każdy składa się z siedmiu utworów ${ }^{12}$. Ze względu na znikomość zachowanych do dziś źródeł francuskiej muzyki organowej przełomu XVI i XVII stulecia kompozycje Titelouze'a stanowią dziś nieocenione świadectwo swojego czasu. Jednocześnie same prezentują dość pokaźny w liczbie materiał muzyczny (95 utworów) oraz przekrój możliwości kompozytorskich i pomysłów twórcy. Autor opatrzył także swe zbiory przedmowami, poświęconymi różnorakim zagadnieniom - głównie wykonawczym i kompozytorskim.

Ukazanie się drukiem Hymnów Titelouze'a było niewątpliwie wydarzeniem pionierskim. Bowiem od roku 1531 - kiedy to w oficynie Pierre'a Attaingnanta w Paryżu ukazały się trzy tomy organowej muzyki liturgicznej ${ }^{13}-$ aż do Hymnów Titelouze’a, według dzisiejszej wiedzy, nie wyszedł drukiem we Francji żaden zbiór kompozycji z bezpośrednim przeznaczeniem na organy. Co więcej, za czasów Titelouze’a tabulatury Attaingnanta prawdopodobnie nie były już znane (względnie mogły uchodzić co najwyżej za legendę). Titelouze sam był świadomy wagi swojego przedsięwzięcia. Pisze bowiem we wstępie:

To, co mnie jeszcze bardziej skłoniło do oddania w ręce zainteresowanych tego skromnego zbioru to fakt, iż widziałem niezliczone woluminy tabulatur na wszystkie rodzaje instrumentów wydane w naszej Francji, zaś jest rzeczą uchodzącą wszelkiej ludzkiej pamięci, by było coś wydane z przeznaczeniem na organy ${ }^{14}$.

Zamiarem kompozytora było zatem niejako uzupełnienie tych zaległości i dostarczenie organistom repertuaru, który byłby w powszechnym użyciu. Tak pisze:

${ }^{12}$ Nie jest to typowe, gdyż zazwyczaj cykle Magnificat składają się z sześciu wersetów organowych. Kompozytor przejawił tu jednak pewien pragmatyzm i zamieścił - jak pisze w przedmowie - „dodatkowy Deposuit potentes, ponieważ w kantyku Benedictus jest siedem wersetów dla organów. W Magnificat, który ma ich tylko sześć, można będzie się posłużyć tym, którym się zechce”. J. Titelouze, Au Lecteur, [w:] tenże, Le Magnificat ou cantique de la Vierge pour toucher sur l'orgue, suivant les huit tons de l'Eglise, Paris 1626, s. II. Wydanie faksymile, red. M. Degrutère, Fuzeau, Courlay 1992.

${ }^{13}$ Tabulature pour le Dieu Dorgues..., Magnificat sur les huit tons avec Te Deum laudamus... (1530), Treze Motetz musicaulx... (1531). Autor powyższych zbiorów pozostaje do dziś anonimowy.

${ }^{14} \mathrm{~J}$. Titelouze, Au Lecteur, [w:] tenże, Hymnes de l'Eglise pour toucher sur l'orgue, avec les fugues et recherches sur leur plan-chant, Paris 1623, s. II. Wydanie faksymile, red. M. Degrutère, Fuzeau, Courlay 1992. 
Zacząłem więc od tych hymnów, które są najczęściej używane w poszczególnych diecezjach, aby dać możliwość przystosowania każdego, mając tutaj takie, których melodie mogą być zastosowane do różnych [tekstów] hymnów, według zwyczaju [poszczególnych] kościołów ${ }^{15}$.

Ponadto w innym miejscu Titelouze podkreśla, że jego Hymny przeznaczone są dla tych, „którzy potrzebują nauki” ${ }^{16}$. Niewątpliwie więc roueński organista zamierzał wskazać jakiś nowy kierunek dla muzyki organowej. A jeżeli weźmiemy pod uwagę licznie wznawiane w tym czasie we Francji postulaty zawarte w Caeremoniale Episcoporum Klemensa VIII z 1600 roku, domagające się oczyszczenia muzyki kościelnej z wszelkiej „piosenki lubieżnej”" możemy sobie wyobrazić, że ówczesny repertuar bazujący głównie na intawolacjach, improwizacjach czy krążących rękopisach wykorzystywał w dużej mierze tematy i gatunki świeckie. Titelouze w swoich Hymnach proponuje coś zgoła innego, odpowiadając tym samym na odgórne oczekiwania. Jego Hymny - jak wskazuje sam tytuł - są na wskroś przeniknięte melodiami chorałowymi: na szeroką skalę wykorzystują technikę cf, zaś zdecydowana większość tematów poddanych technice imitacyjnej wywodzi się również z melodii danego hymnu.

Willi Apel klasyfikuje gatunki stosowane przez Titelouze'a w pięciu grupach ${ }^{18}$ : 1) cf w jednym głosie - ten typ występuje obowiązkowo w utworze otwierającym cykl, 2) cf w różnych głosach (cf migrans) - występuje wyłącznie jako ostatni utwór w cyklu, 3) fuga kilkutematowa - ukształtowana na wzór motetu, w której każdy

15 Tamże, s. III.

${ }^{16}$ J. Titelouze, Au Lecteur, [w:] tenże, Le Magnificat..., s. II.

${ }^{17} \mathrm{~Np}$. Advertissemens aux recteurs... („przepisy dla rektorów, proboszczów, księży i wikariuszy...", tłumaczone z włoskiego i wydawane we Francji aż do lat 40. XVII w.) zakładają, że „udział organów od tak dawna [obecnych] w świętym Kościele ma być z zasady regulowany według dekretu świętego soboru trydenckiego. Tak więc, by nie śpiewać żadnej piosenki lubieżnej, lecz całkowicie odpowiadające czystości świętych misteriów i nabożeństw”. Iean Baptiste de Constanzo, Advertissemens aux recteurs, curez, prestres, et vicaires qui desirent dignement s'acquiter de leur charge, et faire bien et sainctement tout ce qu'appartient à leur office (tłum. J. Culot), Bourdeaus 1613, s. 355-356, www.books.google.pl/books?id=9npowhq16IwC\&pr intsec $=$ frontcover $\& d q=$ inauthor: $\% 22$ Giovanni + Battista + Constanzi $\% 22 \& h l=e n \& s a=X \& e i=$ gbOcUcmDAoXJtQbf1oBQ\&ved=0CC8Q6AEwAA\#v=onepage\&q\&f=false (22.05.2013).

18 W. Apel, Storia della musica per organo e altri strumenti da tasto fino al 1700, tłum. pod kier. P. Neonato, Firenze 1985, s. 734. 
temat zaczerpnięty jest z kolejnego fragmentu cf, 4) cf kontrapunktowany 2-głosowym kanonem - bardzo kunsztowny gatunek, występujący trzy razy, 5) zastosowanie w ciagu całego lub prawie całego utworu nuty pedałowej. Również i ten gatunek zasługuje na szczególną uwagę, zwłaszcza w przykładzie z Annue Christe, gdzie nuta stała w unikatowy sposób umieszczona jest w głosie sopranowym.

Podobnie jak Hymny, również i Magnificaty Titelouze’a związane są ściśle z chorałem. Materiał, na którym mógł się oprzeć kompozytor, jest jednak w Magnificatach zgoła inny. Melodie kantyku nie są tak rozwinięte, jak to ma miejsce w przypadku hymnów. Kompozytor nie może zatem na szeroką skalę stosować techniki cf, gdyż prowadziłoby to nieuchronnie do monotonii (w dosłownym sensie tego słowa). W tej sytuacji Titelouze zastosował inną strategię, tak że zdecydowana większość utworów to zwykłe fugi. Analogicznie jak w fugach ze zbioru Hymnów każdy wers chorałowy wyznaczał nową sekcję kompozycji, narzucając przy tym nowy temat, tak w fugach ze zbioru Magnificat mamy do czynienia z formami dyptykowymi, które w ten sposób odzwierciedlają dwuczęściową budowę melodii kantyku. Po drugie - mając w kantyku Magnificat lub Benedictus siedem utworów w cyklu, a nie - jak to ma miejsce w przypadku hymnów - trzy utwory lub sporadycznie cztery, Titelouze został niemal zmuszony do większego zróżnicowania poszczególnych utworów w zakresie materiału motywicznego. Konsekwencją tego jest wyraźniejsza identyfikacja poszczególnych wersetów pod względem charakteru, a niejednokrotnie widoczne jest zastosowanie przez kompozytora rodzaju ilustracji muzycznej ${ }^{19}$.

Ten związek muzyki ze słowem obecny jest też w innym wymiarze; w przedmowie Titelouze pisze:

Będzie można również przyznać, że zmusiłem większą część fug do wymawiania słów. Jest bowiem rozsądne, aby organy, które grają jako alternatim dany werset, wypowiadały go, jak to tylko możliwe ${ }^{20}$.

Istotnie, tematy fug stworzone przez Titelouze'a, a bazujące na melodiach kantyku w poszczególnych tonach, nie tylko czerpią z kantyku swoją melodykę,

${ }^{19}$ Najbardziej ewidentnym tego przykładem są utwory Deposuit potentes. Tekst tego wersetu zawiera silną antytezę operującą dwoma paradoksami i dzięki temu wręcz prowokuje twórcę do odzwierciedlenia tego w muzyce. Dzieje się to na różne sposoby. Przede wszystkim przez częste skontrastowanie tematów obu sekcji, nadanie im przeciwnych wartości ekspresyjnych, a także skontrastowanie intensywności ruchu rytmicznego obu sekcji. Innym zabiegiem jest wykorzystanie pochodów chromatycznych wznoszących we fragmentach odpowiadających słowom: „wywyższył pokornych”.

${ }^{20}$ J. Titelouze, Au Lecteur, [w:] tenże, Le Magnificat..., dz. cyt., s. II. 
ale co więcej - są tak skonstruowane, że bez większej trudności można by podłożyć pod nie przynajmniej początkowe, najbardziej charakterystyczne słowa danego wersetu kantyku.

W zakresie harmoniki Titelouze stosuje na szeroką skalę wszelkiego rodzaju dysonanse przygotowane, właściwe jego epoce, tj. rozwiązywane w dół i wykorzystujące przede wszystkim diatonikę. Tak tłumaczy to w przedmowie do Hymnów:

Podobnie jak malarz stosuje cienie w swym obrazie, aby lepiej ukazać promienie dnia i jasności, tak samo i my wkładamy dysonanse między konsonanse; takie jak sekundy, septymy i ich pochodne, aby pozwolić jeszcze lepiej dostrzec ich słodkie brzmienie. I te dysonanse dają się słyszeć jako miłe dla ucha, dobrze zastosowane i na swoim miejscu ${ }^{21}$.

Co do chromatyki - Titelouze stosuje ją wyjątkowo ostrożnie, traktując ją niewątpliwie jako nadzwyczajny środek ${ }^{22}$. Pisze:

skoro organy wytworzyć mogą bez trudu wszystkie rodzaje interwałów, zarówno naturalnych, jak i schromatyzowanych, w niektórych miejscach zastosowałem pewne [interwały] nadzwyczajne (jednakowoż dobre i miłe dla ucha), aby nadać temu instrumentowi to, co jest jego specyfiką [...] i zastosowałem nawet krzyżyki w miejscach, w których nie zrobiłbym tego, gdyby to było przeznaczone do śpiewania ${ }^{23}$.

Prawdopodobnie autor mówi tutaj o interwałach melodycznych występujących jak na poniższym przykładzie (ilustr. nr 1).

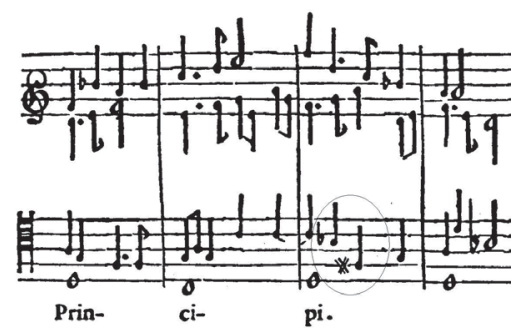

Ilustr. nr 1. J. Titelouze, Ad coenam, 1 verset, t. 39-42.

${ }^{21}$ J. Titelouze, Au Lecteur, [w:] tenże, Hymnes..., dz. cyt., s. III.

${ }^{22}$ Warto zauważyć, że jedynie pięć tematów (spośród z górą dwustu) skomponowanych przez Titelouze'a wykorzystuje chociażby najprostszy pochód chromatyczny.

${ }^{23}$ J. Titelouze, Au Lecteur, [w:] tenże, Hymnes..., dz. cyt., s. III. 
W tego typu zabiegach kompozytorskich widzieć zatem należy świadome nadawanie kompozycji cech instrumentalnych przy równoczesnym odnoszeniu jej do muzyki wokalnej. Co więcej, Titelouze ma świadomość pewnej wyższości kontrapunktu organowego nad kontrapunktem wokalnym. Pisze bowiem w innym miejscu: „te interwały nastrojone mogą otrzymać taki ruch i przebiegi, których nie zastosowano by w śpiewie; tak, że na organach można zastosować kontrapunkt lepszy niż w śpiewie” ${ }^{4}$. Ów „postęp” był niewątpliwie konieczny dla kształtowania się stylu organowego.

Te nowe możliwości brzmieniowe, możliwe do wykonania na klawiaturze - jak pisze Titelouze - „bez trudu”, uwarunkowane są wszak zastosowaniem w organach określonego stroju. Nie przypadkiem pisze Titelouze: „aby naprawdę słyszeć muzykę, którą się gra, trzeba znać porządek dźwięków w instrumencie" ${ }^{25}$. Nie jest żadnym odkryciem stwierdzenie, że na przestrzeni XVI i XVII w. w niemal całej Europie instrumenty klawiszowe strojone były w strojach mezotonicznych, a więc takich, które umożliwiały wykonanie większej bądź mniejszej ilości czystych tercji. Najbardziej klasycznym strojem średniotonowym był taki, w którym kwinty pomniejszone były o 1/4 komatu syntonicznego, a efektem tego było uzyskanie ośmiu tercji czystych ${ }^{26}$. Jeżeli więc badamy w muzyce organowej - w tym przypadku Titelouze’a - pierwiastki ,instrumentalności” tej muzyki, nie możemy nie docenić wagi i wpływu systemów temperacji. Niewątpliwie ten aspekt muzyki organowej i organów budził w kompozytorze zachwyt, kiedy pisał: „instrument [ten] ma w sobie coś szczególnego dzięki swojemu strojowi” ${ }^{27}$.

Dzieło Titelouze’a wydaje się w swojej strukturze kontrapunktyczno-harmonicznej dość monolityczne. Poza pięcioma wyjątkami, wszystkie utwory utrzymane są też w 4-głosie. Brak różnorodności w tym zakresie nadrabiany jest stosowaniem różnorakich technik kontrapunktycznych, o czym była powyżej mowa, albo też sporadycznym rozrzedzeniem faktury. I w tych zabiegach widzimy kolejny aspekt poszukiwania przez Titelouze’a niezależnej drogi i stylu muzyki organowej. Spotkać bowiem można w utworach Titelouze'a fragmenty inspirowane bezpośrednio renesansową polifonią wokalną, jakby wyjęte czy nuta w nutę przepisane z dzieła wokalnego (ilustr. nr 2),

${ }^{24}$ Tamże, s. II.

25 Tamże, s. II.

${ }^{26}$ Źródłem najbliższym Titelouze’owi, opisującym taki sposób strojenia organów, jest traktat Marina Mersenne’a Harmonie universelle...: „trzeba je [kwinty] osłabić o 1/4 komatu”. M. Mersenne, Harmonie universelle, contenant la theorie et le pratique de la musique, S. Cramoisy, Paris 1636, Księga szósta Des orgues, s. 366, [w:] J. Saint-Arroman, J-Ch. Tosi (red.), Méthodes et Traités, Série I France 1600-1800, Orgue, Fuzeau, Courlay 1992, s. 23-128.

27 J. Titelouze, Au Lecteur, [w:] tenże, Hymnes..., dz. cyt., s. II. 

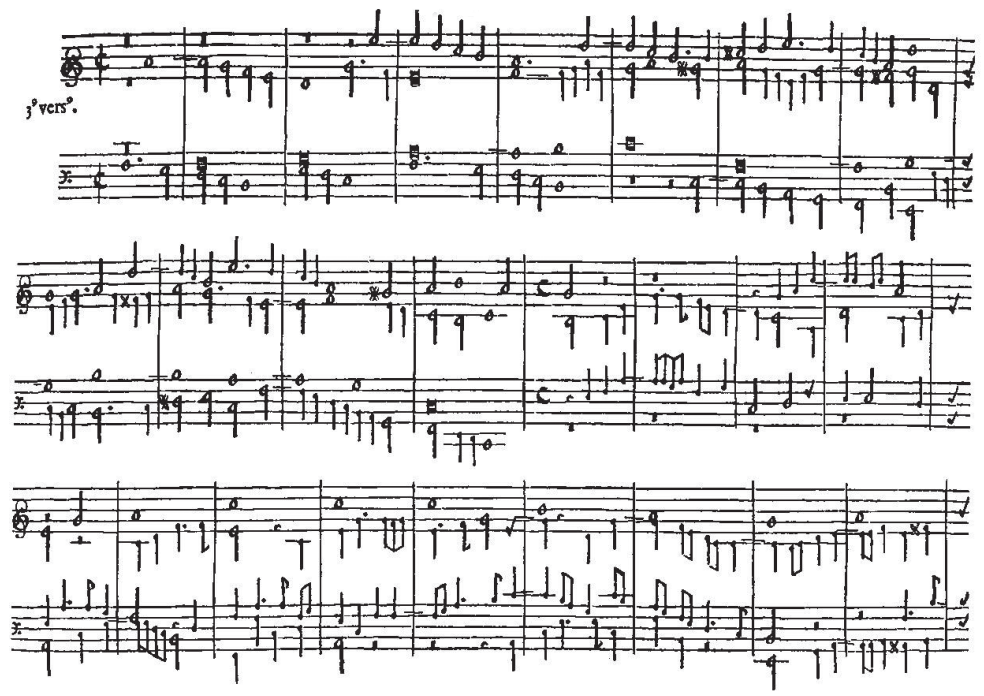

Ilustr. nr 2. J. Titelouze, $A$ solis ortus, 3 verset, t. 1-25.

a z drugiej strony przełamywanie tego stylu coraz to śmielszymi figurami o charakterze instrumentalnym (klawiszowym). Często przypomina to jakby konkurowanie ze sobą idiomu wokalnego $\mathrm{z}$ idiomem organowym, kiedy $\mathrm{w}$ strukturze kompozycji następują nagłe cięcia i przechodzenie z ruchu wokalnego do ruchu instrumentalnego linii melodycznych (ilustr. nr 3).

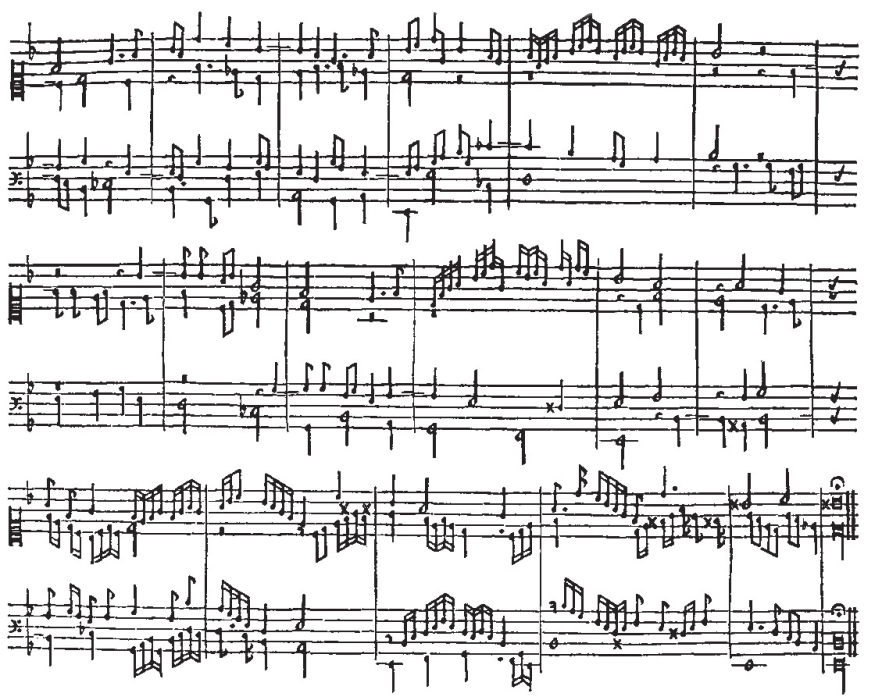


W końcu spotkać możemy pokaźne fragmenty z typowo instrumentalną motywiką. W ten sposób te dwa, z pozoru przeciwne, idiomy i tendencje przenikają się i uzupełniają, tworząc pewną zintegrowaną już wartość stylistyczną (ilustr. nr 4).

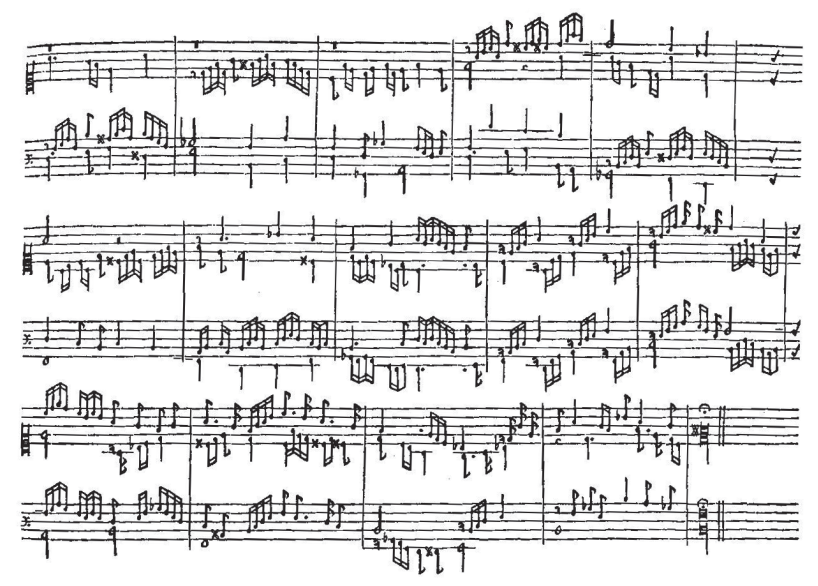

Ilustr. nr 4. J. Titelouze, Urbs Hierusalem, 3 verset, t. 52-66.

Te coraz to żywsze figury melodyczne przyjmują zarazem funkcję ornamentów. Termin ten jest szczególnie jednoznaczny, gdy chodzi o figury stereotypowe, często stosowane. A takich w dziele Titelouze'a nie brakuje. Podstawową figurą ornamentacyjną jest rozbudowany tryl kadencyjny, zwany cadence. Umiejscowiony jest na przedostatniej nucie w kadencji, a rozpoczyna się od nuty górnej (ilustr. nr 5).

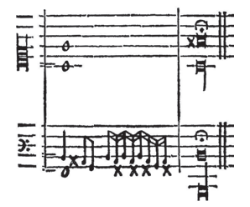

Ilustr. nr 5. J. Titelouze, Magnificat primi toni, Deposuit potentes, t. 38-39.

Chociaż ten typ ornamentów, akcentujących ważne miejsca w utworze, przeznaczony był głównie do kadencji, Mersenne dodaje, że „tryle te [...] służą również do wszystkich rodzajów pasaży" ${ }^{28}$. Przykłady rozpisanych cadences znajdujemy w Magnificatach Titelouze'a. Często poprzedzone są figurą wprowadzającą i zawsze zwieńczone zakończeniem. Opis tego ozdobnika zawarty w Harmonie universelle przemawia za tym, iż cadence rozpoczynała się wolniej i w miarę rozwo-

${ }^{28}$ Tamże; Traitez des Consonances..., Księga szósta De l’art de bien chanter..., s. 355. 
ju była przyśpieszana ${ }^{29}$. Rzuca to niewątpliwie światło na aspekt ekspresji wykonania. Ukazuje to również poniższy przykład autorstwa Titelouze’a (ilustr. nr 6).

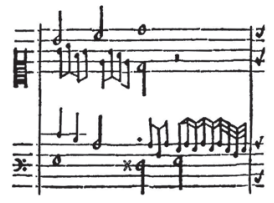

Ilustr. nr 6. J. Titelouze, Magnificat tertii toni, Gloria Patri, t. 12.

Znaleźć także można w utworach Titelouze'a wiele kadencji i pasaży, w których niewątpliwie należałoby cadence wykonać, choć nie jest w żaden sposób zaznaczona. Są też liczne miejsca, gdzie jej obecność można bez trudu domniemywać (ilustr. 7 i 8).

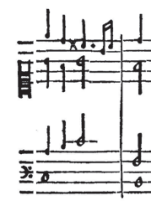

Ilustr. nr 7. J. Titelouze, Magnificat primi toni, Quia respexit, t. 7-8.

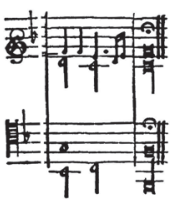

Ilustr. nr 8. J. Titelouze, Magnificat quinti toni, Magnificat, t. $25-26$

Oprócz tego najważniejszego ornamentu linie melodyczne kompozycji Titelouze’a, a zwłaszcza Magnificatów, pełne są wszelkiego rodzaju drobnych figur o charakterze ornamentacyjnym. Ich energiczna rytmika, zazwyczaj kontrastująca $\mathrm{z}$ rytmiką dominującą $\mathrm{w}$ danym fragmencie, pozwala je również bez trudu zidentyfikować jako ozdobniki (ilustr. nr 9 i 10).

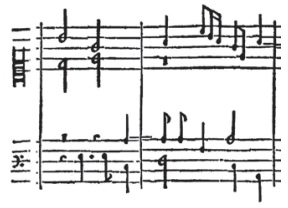

Ilustr. nr 9. J. Titelouze, Magnificat tertii toni, Magnificat, t. 26-27.

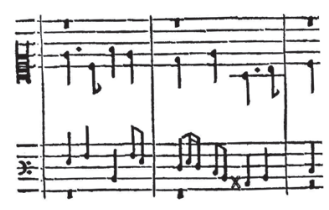

Ilustr. nr 10. J. Titelouze, Magnificat primi toni, Et misericordia, t. 3-5.

Wszystkie przedstawione wyżej figury stanowią o kształtowaniu i definiowaniu organowego charakteru tej muzyki, zaś od strony wykonawczej powinny być inspiracją do dalszego jej ubogacania - według wzorów pozostawionych przez

${ }^{29}$ M. Mersenne, Harmonie Universelle..., Traitez des Consonances..., Księga szósta De l'art de bien chanter..., s. 355. 
twórcę. Ponadto naturalne było w epoce Titelouze’a obfite ubogacanie linii melodycznych krótkim (zazwyczaj trzynutowym) ornamentem, mającym na celu „ożywienie ruchu (śpiewu) głosów”30. O praktyce tego ozdobnika zaświadcza już w połowie XVI w. Thomás de Sancta Maria, nazywając go senzillo i zaznaczając, że należy go wykonywać na co drugiej semiminimie (a więc wcale nie rzadko!). Kierunek ruchu senzillo jest natomiast zawsze przeciwny kierunkowi ornamentowanej melodii ${ }^{31}$.

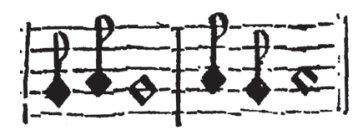

Ilustr. nr 11. Senzillo wedtug Thomása de Sancta Maria (Arte de tañer Fantasia..., s. 47).

I prawdopodobnie ten rodzaj ozdobników miał przede wszystkim na myśli Titelouze, kiedy pisał:

Co do ornamentów (accents), trudność naniesienia znaków przy tak wielkiej liczbie nut, przy których trzeba by to uczynić, skłoniła mnie do pozostawienia tej kwestii osądowi grającego, tak jak robię cadences, które są powszechne, jak też każdy wie ${ }^{32}$.

Niewątpliwie więc był to ornament dobrze znany i zapewne nie nowy, skoro kompozytor zdaje się na osąd wykonawców.

Dodatkowe światło w kwestii ornamentacji rzuca nam po raz kolejny Mersenne. Opisując z entuzjazmem grę Pierre'a de la Barre, wymienia takie ozdobniki stosowane przez wirtuoza: "martelemens, tremblemens, battemens" 33 . Tremblement to oczywiście inna nazwa dla cadence, natomiast martelement oraz battement to ornamenty z nutą dolną - pierwszy dłuższy, drugi prosty, trzydźwiękowy ${ }^{34}$.

30 „Ornamenty polecane są tak w śpiewie, jak i na instrumentach [...], by ożywiały ruch głosów”. J. Titelouze, Au Lecteur, [w:] tenże, Hymnes..., dz. cyt., s. III.

31 Thomás de Sancta Maria, Arte de tañer Fantasia..., Valladolid 1565, cz. I, s. 47, www.petrucci.mus.auth.gr/imglnks/usimg/f/f4/IMSLP203244-PMLP343958-Santa_Maria_Libro_ Primero.pdf (25.05.2013).

32 J. Titelouze, Au Lecteur, [w:] tenże, Hymnes..., dz. cyt., s. III.

${ }_{33}$ M. Mersenne, Harmonie universelle..., Księga szósta Des Orgues, s. 392.

${ }^{34}$ Por. tamże, Księga druga Des Instruments a chordes, s. 80-81. 
Opisane wyżej przejawy krystalizacji idiomu organowego w twórczości Titelouze'a związane są, z jednej strony, z ogólnymi przemianami stylistycznymi w muzyce tego czasu, z drugiej strony, z możliwościami technicznymi instrumentu. Pozostaje nam zatem dotknąć kwestii w pewnym sensie kluczowej dla znaczenia dzieła Titelouze'a w kształtowaniu linii rozwoju muzyki organowej we Francji, mianowicie kwestii samego instrumentu (z jego możliwościami brzmieniowymi), który stanowił niewątpliwie jedną z głównych inspiracji twórczych Titelouze’a.

W związku z konfliktami religijnymi, jakie miały miejsce na przestrzeni XVI w., spora liczba organów we francuskich kościołach uległa zniszczeniu. Zjawisko to było bezpośrednią przyczyną i okazją do wytworzenia się nowych - i w pewnym sensie decydujących o przyszłości - kierunków w budownictwie organowym. Było to związane również z osiedlaniem się w płn. Francji organmistrzów zagranicznych, a zwłaszcza flamandzkich.

W II poł. XVI w. większość organów we Francji posiadało jeden manuał i ewentualnie podwieszony pedał. Począwszy od ostatniej ćwierci stulecia zaczęto uposażać instrumenty w manuał drugi - tzw. positif. Kamieniem milowym w rozwoju francuskich organów był instrument postawiony w roku 1580 w Gisors. W jego dyspozycji (tab. nr 1) zauważamy kilka nowatorskich cech, które będą charakterystyczne w ciągu najbliższych dziesięcioleci czy nawet i stuleci. Są to: 1) rozszerzenie zasięgu klawiatur - w manuałach do czterech oktaw (bez najniższego cis), w pedale dwie oktawy i tercja, 2) obecność wysokiej mikstury Cymbale, będącej przedłużeniem Fourniture, 3) obecność 4’ języka Clairon, będącego przedłużeniem 8' Trompette, 4) obecność Cornetu (o zasięgu 25 klawiszy, począwszy od c razkreślnego) służącego zarówno do prowadzenia solowej melodii, jak i do wzmacniania języków w ich górnych, słabszych partiach, 5) obecność pozytywu i jego nowa koncepcja jako zminiaturyzowanej repliki manuału głównego, z możliwością zastosowania plain jeu, a także z językiem Cromorne (odpowiadającym niejako Trompette w manuale głównym) $)^{35}$, obecność w pedale dwóch niezależnych głosów 8': Flet i Trąbka.

\begin{tabular}{|l|l|l|}
\hline G.O. $(48$ klawiszy) & Positif (48 klawiszy) & Pédale $(28 \text { klawiszy })^{1}$ \\
\hline Montre 16' & Bourdon 8' & Bourdon 8' \\
\hline Montre $8^{\prime}$ & Prestant 4' & Trompette 8' \\
\hline Bourdon 8' & Doublette 2' & \\
\hline Prestant 4' & Larigot (Quinte) & \\
\hline
\end{tabular}

35 Francuskie organy renesansowe mogły wprawdzie posiadać pozytyw, był on jednak pomyślany na zasadzie kontrastu brzmieniowego w stosunku do manuału głównego, gdyż posiadał zazwyczaj parę łagodnych głosów. 


\begin{tabular}{|l|l|l|}
\hline Doublette 2' & Cymbale II & \\
\hline Fourniture IV & Cromorne 8' & \\
\hline Cymbale III & & \\
\hline Flûte 4' & & \\
\hline Gros nasard II & & \\
\hline Sifflet (quarte) & & \\
\hline Tiercelette (Flûte à biberon) & & \\
\hline Cornet d'écho V & & \\
\hline Trompette 8' & & \\
\hline Clairon 4' & & \\
\hline Régale (voix humaine) & & \\
\hline
\end{tabular}

Liczba klawiszy w pedale wg: N. Dufourq, Le livre de l'Orgue Français, t. III, cz. 1 La facture de la première à la seconde Renaissance, Paris 1975, s. 174.

Tab. nr 1. Dyspozycja organów w Gisors zbudowanych przez Nicolasa Barbier w latach 1578-8036.

Inne charakterystyczne cechy nowego typu instrumentu to obecność fletowego głosu 1', a także pryncypałowej tercji, która wchodziła w skład plain jeu. Od pierwszych lat wieku XVII na północy kraju, a zwłaszcza w Paryżu, taki dwumanuałowy instrument z pedałem stawał się normą.

Przełom XVI i XVII w. to okres prawdziwej ekspansji i rozkwitu głosu Cornet. Ok. 1620 roku głos ten był już obecny we wszystkich ważniejszych organach we Francji. Na początku występował on wyłącznie jako jeden z głosów manuału głównego. Pod koniec lat dwudziestych XVII w. zaczęły natomiast pojawiać się instrumenty o trzech klawiaturach, w których manuał trzeci, zwany Récit lub Echo, posiadał skalę dwóch górnych oktaw i obsługiwał właśnie Cornet ${ }^{37}$. Poszczególne składniki Cornetu nie były w tym czasie tak dookreślone, jak się postrzega ten głos dzisiaj. Ilość rzędów w Cornecie mogła się wahać od 3 do 7; mógł być też Cornet progresywny bądź połączony z głosem językowym. Coraz szersze zastosowanie tego rejestru i poszukiwania subtelności brzmienia doprowadziły do wyodrębnienia się jako osobnego głosu jego najbardziej charakterystycznego składnika, tj. tercji. W ten sposób obok tercji pryncypałowej dysponowano instrumenty w tercję fletową ${ }^{38}$.

36 Dyspozycja wg dokumentów N. Barbiera z lat 1577-80, [za:] M. Baudot, Notice historique sur les orgues de l'Eglise Saint-Gervais et Saint-Protais de Gisors, Gisors 1928, s. 7-8, www.orgue. gisors.free.fr/histo.html (27.05 2013).

${ }^{37} \mathrm{~Np}$. organy w katedrze w Bordeaux zbudowane przez Valérana de Hémana w roku 1627.

${ }^{38} \mathrm{~Np}$. organy w kościele St-Nicolas-des-Champs w Paryżu zbudowane przez Crespina Carliera w roku 1632. 
W jaki sposób i w jakim kierunku przedstawione wyżej tendencje w budownictwie organowym wywierały wpływ na twórczość organową Titelouze’a? Naturalną konsekwencją możliwości technicznych i brzmieniowych instrumentów była praktyka rejestracji. Niestety, mimo zaangażowania i aktywności Titelouze'a na polu organologicznym nie zawarł on w przedmowach (ani w żadnych innych znanych nam tekstach) informacji dotyczących praktyki rejestrowania. W przedmowie do Hymnów ujawnia jednak inną, ogólniejszą zasadę, powiązaną z rejestracją:

\begin{abstract}
w ostatnich latach przydaliśmy [organom] jeszcze więcej doskonałości, budując w wielu miejscach Francji instrumenty o dwóch oddzielnych klawiaturach manuałowych oraz klawiaturze nożnej, której podstawą jest głos 8-stopowy, i zawierającej dwadzieścia osiem lub trzydzieści klawiszy zarówno chromatycznych, jak i diatonicznych, na której [to klawiaturze] można wykonywać bas oddzielnie, bez grania go rękami, tenor na drugiej klawiaturze, zaś alt i sopran na trzeciej ${ }^{39}$.
\end{abstract}

W tekście tym dostrzec można pewną wizję brzmieniową Titelouze'a, dowartościowującą linearyzm prowadzenia głosów. Pisze dalej Titelouze: „Dzięki temu może się uwydatnić unison, krzyżowanie głosów i tysiąc innych rodzajów figur muzycznych" ${ }^{40}$. Taki sposób rozmieszczenia całej tkanki polifonicznej kompozycji był we Francji niewątpliwą nowością. Co więcej, ten priorytet (uwypuklania linii poszczególnych głosów) uwidacznia się nie tylko na etapie wykonania utworu, lecz także na etapie komponowania. Autor świadomie wykorzystuje

możliwości instrumentu, w którym duża rozpiętość klawiatury może z powodzeniem służyć do [...] rozmieszczania poszczególnych głosów w dużej odległości od siebie, [...] by były lepiej słyszalne ${ }^{41}$.

Trzeba przy tym zauważyć, że w porównaniu z muzyką organową innych krajów tego czasu w kompozycjach Titelouze’a notujemy wyjątkowo mało przypadków krzyżowania głosów (właśnie dzięki rozmieszczaniu głosów w dużej odległości od siebie). Jest to korzystne szczególnie w opcji wykonania na jednym manuale; możliwość, o której pisał Titelouze, użycia trzech klawiatur nie jest bowiem obligatoryjna. Co więcej, sposób zapisu kompozycji i zastosowania kustoszy, oznaczających przejęcie danego głosu z jednej ręki przez drugą, świadczy

\footnotetext{
${ }^{39}$ J. Titelouze, Au Lecteur, [w:] tenże, Hymnes..., dz. cyt., s. II.

40 Tamże.

${ }^{41}$ Tamże, s. III.
} 
o przeznaczeniu obu zbiorów na instrument o jednym manuale bez pedału. Postawić można jednak śmiałą tezę, że sposób rozdzielenia brzmieniowego poszczególnych głosów, opisany przez kompozytora, nie jest bynajmniej jedyną możliwością w tym zakresie. Czy nie wyraża on raczej ogólnej tendencji, która zaczęła w tym czasie dochodzić we Francji do głosu? Tak więc konsekwencją tego będzie stosowanie również innych układów rozdziału głosów między klawiatury - zależnie od możliwości, jakie daje wykonawcy dana kompozycja. Stosunkowo najprostszą możliwością i dającą się zastosować w zdecydowanej większości utworów jest wykonanie na jednym manuale oraz pedale (dla głosu basowego). W tym czasie budowano wszak organy o jednej klawiaturze manuałowej i niezależnym pedale. Wydzielenie samego głosu basowego przynosi już pewne efekty brzmieniowe, które, co więcej, były na terenie Francji nowością, biorąc pod uwagę fakt, iż pedał w organach renesansowych bazował na kilku (dwóch do sześciu) klawiszach. Nie było więc mowy, by mógł wykonywać rozbudowane linie melodyczne, jakie spotykamy u Titelouze'a. Innym możliwym układem rozmieszczenia głosów między klawiatury jest wykonanie dwóch górnych głosów na jednym manuale, a dwóch dolnych na drugim. Taką opcję umożliwia faktura pewnej części kompozycji, a niektóre mogą do niej wręcz prowokować ${ }^{42}$. Pozostaje jeszcze do rozstrzygnięcia jedna możliwość, mianowicie uprzywilejowanie sopranu. Taki układ brzmieniowy niewątpliwie będzie wiódł prym w następnych dziesięcioleciach, w epoce klasyków. Nie jest on jednak wynalazkiem II poł. XVII stulecia. W ostatnich dziesięcioleciach XVI w. coraz częściej wyposażano organy w Cornet, i to właśnie obecność tego głosu najbardziej sprzyjała i stymulowała praktykę prowadzenia solowej melodii w sopranie. Wiemy np., że w roku 1586 Jean Langhedul dodał w organach kościoła Augustianów w Paryżu Cornetz à boucquin, „zaczynając na [dźwięku] c [...], które jest na środku klawiatury, i kontynuując przez całą klawiaturę do góry”³. Ponadto Langhedul dodał do jedynego Fletu 3' w pozytywie Flet 6’ „do grania razem z głosem Cornet, aby wszystko dobrze brzmiało i stroiło" ${ }^{44}$. Na przełomie XVI i XVII w. budowano we Francji także instrumenty o dzielonej klawiaturze. Takie rozwiązania w naturalny sposób inspirowały do wyodrębniania brzmie-

${ }^{42}$ Np. Gloria Patri z Magnificatu septimi toni, w której rozpoznajemy pewne pozostałości z techniki 2-chórowej.

${ }^{43}$ Z kosztorysu remontu organów w kościele Augustianów w Paryżu, [w:] J. Zoutendijk, Le cornet de Flandres. De ontwikkeling van de Cornet en gedeelde registers in het Zuid-Nederlandse cultuurgebied tot ca. 1800, 2010, s. 25, www.orgelhistorie.org/archives/12/de-geschiedenisen-ontwikkeling-van-het-register-cornet (29.05.2013).

${ }^{44}$ Tamże, s. 25. 
niowego sopranu. Przykładem jest anonimowy zbiór opatrzony datą $1617^{45}$, w którym jeden z wersetów Magnificatu w II tonie zawiera wskazówkę wykonania na „rejestrach dzielonych”. Wszelako wydaje się, iż Titelouze nie był skłonny zaadaptować do swych dzieł tej maniery. W żadnej bowiem z jego kompozycji użycie jakiegokolwiek głosu dzielonego, jak również Cornetu na oddzielnej klawiaturze, nie jest możliwe. Jeżeli nawet odległości między głosami pozwalają na poprowadzenie sopranu na oddzielnej pełnej klawiaturze, to zwykle jednak rozwiązanie takie wydaje się wymuszone ${ }^{46}$.

Przedstawione wyżej elementy warsztatu kompozytorskiego oraz poglądów na muzykę organową Titelouze'a przemawiają za uznaniem doniosłej roli, jaką $\mathrm{w}$ procesie kształtowania się idiomatycznych cech francuskiej muzyki organowej XVII w. odegrała jego twórczość. Mając swoje źródło w muzyce wokalnej, dzieło Titelouze'a rozwija techniki kompozytorsko-wykonawcze o charakterze instrumentalnym, organowym. Jest ważnym elementem w mozaice ogólnoeuropejskich przemian i krystalizacji stylu organowego, a równocześnie unikatowym świadectwem na gruncie francuskim muzyki organowej tego czasu.

\section{The work of Jehan Titelouze and its place in developement of organ style}

The organ work of Jehan Titelouze has considerable meaning in developement of organ music in France. His two books: Hymnes de l'Eglise pour toucher sur l'orgue, avec les fugues et recherches sur leur plain-chant (1623) and Le Magnificat, ou cantique de la Vierge pour toucher sur l'orgue, suivant les huit tons de l'Eglise (1626) are a great testimony of french organ music at the beginnig of XVIIth century. Titelouze is considered both a traditionalist and an innovator. His organ style is firmly rooted in the structures and the compositional techniques of the renaissance polyphony. The significant inspiration for Titelouze was a new invented type of organ. Composer in a conscious way used its

45 Przechowywany w British Library, Add. MS 29486.

${ }^{46}$ Bodaj jedynym wyjątkiem może być 3-głosowy kanon z hymnu Veni Creator, gdzie taki układ zdaje się być sugerowany poprzez zapis i fakturę. 
technical and sound possibilities for create new stuctures with diligent counterpoint, organ ornamentation and the linear stucture.

Stowa kluczowe francuska muzyka organowa, hymny, muzyka liturgiczna, Magnificat, organy, polifonia renesansowa, Jehan Titelouze

Keywords french organ music, hymns, liturgical music, Magnificat, organ, organ building, organ ornamentation, organ style, renaissance polyphony, Jehan Titelouze 